\title{
South Florida Tropical Fruit Grower Perspectives: Water Conservation Management Practices ${ }^{1}$
}

\author{
Kati W. Migliaccio, Jonathan H. Crane, Edward Evans, Bruce Schaffer, Yuncong Li, and Rafael \\ Muñoz-Carpena ${ }^{2}$
}

\section{Introduction}

The 2007 Census of Agriculture showed that Miami-Dade County had about 67,050 acres of agriculture land which was less than that reported in the 2002 Census of Agriculture (90,000 acres). The 67,050 acres reported in 2007 was distributed among 2,498 farms. This was an increase from the 2002 Census of Agriculture which reported 2,244 growers. Of the total farms, $71 \%$ in 2007 and $63 \%$ in 2002 were less than 10 acres and $93 \%$ in 2007 and $89 \%$ in 2002 were less than 50 acres in size. In 2007, the market value of agricultural products sold in Miami-Dade County was about \$661 million which was an increase from the $\$ 578$ million market value of 2002 .

Subtropical and tropical fruit production in Miami-Dade County was estimated to cover 11,365 acres in 2007, a reduction from the 12,862 acres reported in 2002. The main crops are avocado ( $60 \%$ of the acreage), mango, carambola, lychee, longan, mamey sapote, banana/plantain, papaya, and guava. Minor crops include sapodilla, jackfruit, sugar apple, atemoya, star apple, pitaya, passion fruit, canistel, and white sapote. Demographically the commercial horticulture industry in Miami-Dade County is very diverse with roughly $60 \%$ of all producers having limited horticulture background (novice growers) and $60 \%$ of all producers being part-time commercial growers (TREC Strategic Plan, 2005). Due to increasing urbanization and growing concerns about water quality and quantity in south Florida, information on the views and practices of growers are essential for developing and promoting cost-effective conservation practices that will benefit both producers and consumers.

Results presented here are from a two part survey designed to assess changing views of local agricultural producers in Miami-Dade County from 2006 to 2009 regarding water quantity and quality management practices. Information from these surveys will be used to tailor future research and extension programs. Although the surveys targeted fruit and ornamental crop growers, only the fruit grower responses are reported in this publication.

1. This document is ABE 368, from the Department of Agricultural and Biological Engineering, Florida Cooperative Extension Service, Institute of Food and Agricultural Sciences, University of Florida. First Published: July 2006. Revised November 2009. Please visit the EDIS Web site at http://edis.ifas.ufl.edu.

2. Kati W. Migliaccio is Extension Specialist, Tropical Research and Education Center (TREC), Homestead, FL; Jonathan H. Crane is Extension Specialist,

TREC, Homestead, FL; Edward Evans is Extension Specialist, TREC, Homestead, FL; Bruce Schaffer is Professor, TREC, Homestead, FL; Yuncong Li is Extension Specialist, TREC, Homestead, FL; Rafael Muñoz-Carpena is Extension Specialist, Agricultural and Biological Engineering, Gainesville, FL

The Institute of Food and Agricultural Sciences (IFAS) is an Equal Opportunity Institution authorized to provide research, educational information and other services only to individuals and institutions that function with non-discrimination with respect to race, creed, color, religion, age, disability, sex, sexual orientation, marital status, national origin, political opinions or affiliations. U.S. Department of Agriculture, Cooperative Extension Service, University of Florida, IFAS, Florida A. \& M. University Cooperative Extension Program, and Boards of County Commissioners Cooperating. Millie Ferrer-Chancy, Interim Dean 


\section{Methods}

The Water Conservation Survey (WCS) was developed by extension agents at the Miami-Dade/IFAS Cooperative Extension Service and extension specialists at the University of Florida, Tropical Research and Education Center (TREC) in Homestead, FL. Once completed, the survey instrument was submitted to the University of Florida Institutional Review Board for approval. Participation was voluntary and anonymity was assured. This two-part survey was conducted as part of a USDA CSREES funded project. Part 1 was the initial survey conducted in 2006 and part 2 was the post project survey conducted in 2009.

Survey questions were either multiple choice or "yes/no". Questions were arranged in 3 categories: background (8 questions), water quality and quantity opinions related to the home (7 questions), and water quality and quantity related to agriculture (12 questions). The background category was designed to collect general information from the respondents such as their orchard acreage, experience, and age. The water quality and quantity opinions related to the home category were included to gain insight into the everyday lifestyle of the respondents and their activities related to water conservation. The water quality and quantity questions related to agriculture category were designed to assess the current perceptions and practices of the respondents, focusing on best management practices (BMPs) for water conservation.

The survey was mailed to fruit growers identified on a mailing list provided by the Miami-Dade County Cooperative Extension Service. In addition, an on-line survey was posted on Florida Agricultural BMP Blog (FABB) (http://fabb.ifas.ufl.edu). The survey was further advertised to local growers through their local organizational meetings. The initial survey was distributed in February 2006 and responses received by the end of March 2006 were tabulated. Approximately 240 surveys were mailed to fruit growers. Of this a total 58 were returned resulting in a response rate of $24 \%$. The post survey was mailed on June 2009 and results were tallied in July 2009. Surveys were sent to the same grower list (with the exception of survey addresses that were returned by the USPS as 'no longer at this address') with 221 surveys mailed and with a $31 \%$ response rate. This was within the response range $(10-50 \%)$ of other surveys (Nachmias and Nachmias, 1976; Neuman, 1997; Donan et al., 2000).

\section{Current Demographics}

Twenty-two percent of the respondents indicated that they relied on farming as their primary source of income, while a larger percentage (33\%) considered themselves full time growers according to the 2006 survey. Similar findings were reported by the 2009 survey. This result is not surprising as many of the growers are part-time while others do not rely on farming as their only source of income.

Most of the orchards (57\%) were between 1 to 9 acres. Ninety-four percent of fruit growers reported the size of their production unit as less than 49 acres. The majority (84\%) of tropical fruit growers were over the age of 51 , with $28 \%$ over 70 years of age in the 2006 survey. The 2009 survey indicated that the majority of growers were over the age of 41 (96\%), with $33 \%$ over the age of 70 .

\section{Water Quality and Quantity Opinions: Everyday Lifestyle}

Fruit growers indicated that they actively conserved water in their homes. More than $70 \%$ of respondents reported not running the water faucet continually while brushing their teeth, not leaving lawn water hoses on longer than necessary, not running the dishwasher unless full, and not taking exceedingly long showers in the 2006 survey. The only notable change in these numbers between the 2006 and 2009 was an increase in the percentage of respondents not running the water faucet continually while brushing their teeth (from $72 \%$ in 2006 to $91 \%$ in 2009) and not running the dishwasher unless full (from $72 \%$ in 2006 to $89 \%$ in 2009). In 2006, 81\% of fruit growers were also interested in learning additional lifestyle changes that would conserve water. However, $23 \%$ felt that the actions they practiced to conserve water would not make a long-term difference. These numbers were similar for 2009 , with $93 \%$ of fruit growers showing increased interest in learning about additional water conservation practices. 
The initiative shown by fruit growers to participate in water conservation practices in their home suggests some personal acknowledgement of the value (economic or environmental) of our water supply. The presence of this attitude is very encouraging and likely provides some existing behavioral groundwork for introducing and implementing water conservation practices in their agricultural enterprises.

\section{Water Quantity and Quality Practices: Agriculture}

In Florida, water conservation in agriculture is a major concern as evidenced by the development of commodity and regionally based Best Management Practice (BMP) manuals. The implementation of BMPs is being encouraged by the Florida Department of Environmental Protection (FDEP) through their incentive of Presumption of Compliance (For more information on the BMP process, see Migliaccio et al., 2006). Hence, survey questions regarding these issues were included.

Of the fruit growers surveyed in 2006, $78 \%$ indicated that they would implement BMPs under the FDEP presumption of compliance incentive. However, $66 \%$ reported they would not spend more than $\$ 500$ to implement the BMPs. These numbers were different in 2009 with only $62 \%$ indicating they would be interested in the FDEP program and only $47 \%$ would implement practices that cost less than $\$ 500$ to implement.

This suggests that cost sharing would be essential for some growers to implement BMPs. On the other hand, if BMPs were shown to be economically beneficial, around $90 \%$ indicated their willingness to implement such practices for both survey years. These results suggest the importance of economic analysis of BMPs and the transfer of this information to growers for their assessment and incorporation into everyday practices. Further discussion is provided on water-quantity and water-quality-based BMPs.

\section{Water Quantity BMPs}

Water quantity BMPs refer to management practices that conserve the amount of water used. The goal of implementing water quantity BMPs is to use water more efficiently so that less volume is required.

Several practices were suggested in the survey as potential water saving measures. Each of these was identified as being used or not used on the growers' farms in the past 5 years (Table 1).

In addition, each grower ranked the applicability of each of the practices (from Table 1). (All results related to the applicability of the practices are not presented but summarized in the following text.) Fruit growers identified the least applicable practice as growing mainly drought tolerant plant species in the 2006 and 2009 surveys, with 22\% reporting this practice as somewhat applicable or very applicable in 2006 and $9 \%$ reporting this practice as somewhat applicable or very applicable in 2009. Similar results were presented by Muñoz-Carpena et al. (2003) who found $21 \%$ of fruit growers were growing drought-tolerant fruit crops and that only an additional $7 \%$ indicated future plans to consider drought-tolerant plant species.

The most applicable water conservation practice identified by the survey was irrigating mainly in the early morning or late evening. Fifty-five percent of fruit growers indicated that this practice was very applicable with another 19\% marking it as somewhat applicable in 2006. Values for 2009 were similar with $69 \%$ indicating the practices as very applicable and $16 \%$ identifying it as somewhat applicable. This was similar to previous survey results (Muñoz-Carpena et al., 2003) which indicated that $83 \%$ of fruit growers irrigated in the morning or late evening.

Monitoring of plant growth stages for irrigation received a variety of responses from $33 \%$ indicating it was very applicable to $17 \%$ indicating it was not applicable in the 2006 survey. The 2009 survey suggested more growers consider this practice as not useful with $24 \%$ indicating it as not applicable and only $16 \%$ suggesting it was very applicable.

Other methods of monitoring plant needs for irrigation include soil moisture monitoring and 
weather monitoring. Monitoring field soil moisture for irrigation management was considered a very applicable water conservation practice by $31 \%$ of fruit growers in 2006 and $24 \%$ of fruit growers in 2009. A greater percentage in both surveys $(47 \%$ in 2006 and $51 \%$ in 2009) indicated that monitoring weather was a very applicable water conservation practice. This coincides with additional survey results that showed a large percentage of fruit growers had monitored local weather to regulate irrigation within the past 5 years (69\% in 2006 and $78 \%$ in 2009). Fewer growers reported using soil moisture monitoring to determine irrigation needs (26\% in 2006 and $31 \%$ in 2009) (see Table 1).

\section{Water Quality BMPs}

Water quality BMPs refer to practices that improve the quality of water by minimizing the potential for contaminating local water resources. The goal of water quality BMPs is to protect water supplies so that they are sufficient for meeting designated uses. Water quality BMPs were assessed by the growers responding to the survey with regards to their use of the practice in the past 5 years (Table 2).

Growers provided additional information on the practices listed in Table 2 by indicating their applicability. The most applicable practice was monitoring of local weather conditions to minimize use of agrochemicals immediately preceding a rainfall event (53\% in 2006 and 51\% in 2009 responding as very applicable). The three remaining practices (i.e., application of nutrients based on soil sampling, application of nutrients based on plant tissue analysis, and application of agrochemicals using a calibrated chemical injector) results were inconclusive with 22 to $26 \%$ responding as very applicable and 24 to $26 \%$ responding as not applicable in the 2006 survey. The 2009 survey results showed an increase in the percentage of growers who indicated that each of these three practices were not applicable.

\section{Extension - Information Transfer}

When asked, the growers identified cost $(57 \%$ in 2006 and $67 \%$ in 2009) as the primary reason for not implementing a practice. However, in 2006 22\% indicated that lack of basic knowledge regarding a technology and its implementation could deter their implementation of a practice. This number was reduced in the 2009 survey to only $11 \%$.

Fruit growers who responded to the survey indicated their preferred method of information transfer was Extension fact sheets (53\% in 2006 and $47 \%$ in 2009), followed by short courses ( $31 \%$ in 2006 and $40 \%$ in 2009). This is understandable since the majority of fruit growers do not earn their income primarily from farming; therefore, fact sheets and short courses are likely to be more accommodating to their schedules.

\section{Summary}

This survey was conducted to determine the current perspectives of local fruit growers in regards to water conservation practices. Results indicated that growers are predominantly working on small acreage, predominantly over the age of 41 , and only a small portion consider themselves full time growers. The majority of survey respondents practice water saving measures at home and indicated an interest in learning about additional conservation measures. There was a reduction from 2006 to 2009 in the percentage of fruit growers interested in implementing BMPs under the FDEP presumption of compliance incentive. The predominant practice already in use by fruit growers for both water quantity and quality was monitoring of weather to determine irrigation scheduling and for determining when best to apply agrochemicals. An alternative to this approach to irrigation scheduling would be to use an automated system (such as a system operating based on historic evapotranspiration or a system that monitors weather parameters directly and automatically regulates irrigation rates and/or frequencies accordingly). Transfer of water conservation information is most beneficial to growers if presented in an Extension fact sheet (i.e., EDIS publication) or a short course (1 to 2 hours).

\section{References}

Donan, A.H., R. Kreutzwiser, and R. de Loë. 2000. Rural water use and conservation in southwestern Ontario. J. Soil and Water Conservation 55:161-171. 
Migliaccio, K. W. and B. J. Boman. 2006. Total

Maximum Daily Loads and Agricultural BMPs in

Florida. ABE362, Agricultural and Biological

Engineering Department, Florida Cooperative

Extension Service, Institute of Food and Agricultural

Sciences, University of Florida.

http://edis.ifas.ufl.edu/AE388

Muñoz-Carpena, R., J. H. Crane, G. D. Israel, and C. F. Balerdi. 2003. Tropical Fruit Growers

Water Use and Conservation Practices in

Miami-Dade County. ABE345, Agricultural and

Biological Engineering Department, Florida

Cooperative Extension Service, Institute of Food and

Agricultural Sciences, University of Florida.

http://edis.ifas.ufl.edu/AE257

Nachmias D. and C. Nachmias. 1976.

Research Methods in the Social Sciences. St. Martins

Press, New York.

Neuman, L.W. 1997. Social Research Methods:

Qualitative and Quantitative Approaches. $3^{\text {rd }}$ ed.

Allyn and Bacon Publ., Boston.

TREC Strategic Plan. 2005. Available at

http://trec.ifas.ufl.edu/doc/StrategicPlan.pdf

Accessed on May 2, 2006. 
Table 1. Water quantity practices and survey response by fruit growers from 2006 and 2009 surveys.

\begin{tabular}{||l|c|c||}
\hline \hline Management Practice & $\begin{array}{c}\text { \% of Growers Using the } \\
\text { Practice 2006 }\end{array}$ & $\begin{array}{c}\text { \% of Growers Using the } \\
\text { Practice 2009 }\end{array}$ \\
\hline Growing mainly drought tolerant plant species & 16 & 9 \\
\hline Irrigating mainly in the early morning or late evening & 72 & 76 \\
\hline $\begin{array}{l}\text { Monitoring plant growth stages (phenology) and irrigating } \\
\text { accordingly }\end{array}$ & 40 & 29 \\
\hline Monitoring container or field soil moisture & 26 & 31 \\
\hline $\begin{array}{l}\text { Monitoring the weather and only irrigating during periods of } \\
\text { dry weather }\end{array}$ & 69 & 78 \\
\hline None & 0 & 2 \\
\hline Other & 14 & 13 \\
\hline \hline
\end{tabular}

Table 2. Water quality practices and survey response by fruit growers from the 2006 and 2009 surveys.

\begin{tabular}{||l|c|c||}
\hline \hline Management Practice & $\begin{array}{c}\text { \% of Growers Using } \\
\text { the Practice in 2006 }\end{array}$ & $\begin{array}{c}\text { \% of Growers Using the } \\
\text { Practice in 2009 }\end{array}$ \\
\hline Application of nutrients based on soil sampling & 19 & 16 \\
\hline $\begin{array}{l}\text { Application of nutrients based on plant tissue } \\
\text { analysis }\end{array}$ & 29 & 27 \\
\hline $\begin{array}{l}\text { Monitoring local weather to avoid application of } \\
\text { agrochemicals immediately preceding a rainfall } \\
\text { event }\end{array}$ & 72 & 73 \\
\hline $\begin{array}{l}\text { Application of agrochemicals using a calibrated } \\
\text { chemical injector with drip or micro irrigation }\end{array}$ & 26 & 9 \\
\hline None & 9 & 22 \\
\hline Other & 10 & 2 \\
\hline
\end{tabular}

